\title{
But Who Will Get Billy? The Effect of Child Custody Laws on Marriage ${ }^{1}$
}

\author{
Elaina Rose \\ University of Washington \\ Crystal (Ho Po) Wong \\ West Virginia University
}

October 2014

\begin{abstract}
Under the tender years doctrine in effect until the 1970's, custody was virtually always awarded to the mother upon divorce. Gender-neutral custody laws introduced beginning in the 1970's provided married fathers, in principle, equal rights to custody. Subsequent marriage-neutral laws extended the rights to unmarried fathers. We develop a theoretical model of the effect of custody regime on marriage and test the model's predictions using a unique data set that merges custody law data with data from the Current Population Survey and Vital Statistics. We find that, under marriage non-neutrality, the introduction of gender-neutral laws reduced the hazard into marriage by at least 7.9 percent. There is no evidence that moving from marriage non-neutrality to marriage neutrality affected marriage under the gender-neutral custody regime.
\end{abstract}

Keywords: Marriage, Custody, Family Law

JEL Code: J1, J12, J16, J18, K36

\footnotetext{
${ }^{1}$ We wish to thank Neil Bruce, Nick Huntington-Klein, Tak-Yuen Wong for helpful discussions. Correspondence: Rose: erose@u.washington.edu, Wong: howong@mail.wvu.edu
} 
Joanna Kramer: "I'm not saying he doesn't need his father but I really believe he needs me more. I'm his mother."

Ted Kramer: "What law is it that says that a woman is a better parent simply by virtue of her sex?"

(Kramer vs. Kramer, Columbia 1979)

\section{Introduction}

The divorce revolution of the 1960's and 1970's entailed major changes in family law. Prior to the revolution, divorce could only be obtained with consent of both parties, or with proof of fault. The conditions relaxed substantially throughout the revolution. By 2010, unilateral divorce prevailed in all 50 states. Property distribution and custody laws changed along with the new unilateral divorce laws in order to protect spouses disadvantaged by the loss of a marriage.

The legal changes were accompanied by a dramatic transformation of family structure. Divorce, non-marriage, cohabitation and women's labor force participation rates have all increased. Non-marital childbearing has skyrocketed. The question for researchers is whether the relationships are causal.

Many studies conclude that the introduction of unilateral divorce caused at least some part of the increase in the divorce rate (Peters 1986; Allen 1993; Friedberg 1998; Wolfers 2006). Others report an increase in female labor force participation and a decline in marriage-specific human capital investment in response to the new laws (Johnson \& Skinner 1986; Stevenson 2007). Unilateral divorce led to a decline in the likelihood that a woman would become a victim

of suicide or spousal homicide (Parkman 1992; Stevenson \& Wolfers 2006). Clearly, some women were made better off by access to unilateral divorce.

However, the increased ease of divorce left other women worse off. Many women's economic well-being deteriorated as husbands generally had more labor market human capital and greater control over household assets. Recognition of wives' economic vulnerability spurred changes in marital property distribution laws to transfer resources from divorcing husbands to 
their wives. Under the new equitable distribution regimes the issues became: (1) what assets are considered marital property, and (2) how the property is to be divided.

In terms of custody rights, fathers were the vulnerable partners. Under the traditional tender years doctrine in effect prior to the revolution, custody virtually always went to the mother in the event of divorce. Fathers' rights groups argued that the maternal preference in child custody violated their rights to due process and equal rights protection. In response, new laws recognizing fathers' rights were introduced. Gender-neutral laws granted courts greater latitude to grant custody to married fathers. Subsequent marriage-neutral laws granted similar rights to unmarried fathers. At the present time, custody laws in at least 21 states are both marriage and gender-neutral. ${ }^{2}$

Fathers are now far more likely to gain custody relative to the pre-divorce revolution era. While most custodial parents are still mothers, between 1958 and 1989 the number of father-only families increased by almost 300 percent, with most of the growth occurring after 1973 (Meyer \& Garasky 1991). In 2009, there were almost 2.5 million custodial fathers in the United States, with 1 in 6 custodial parents being fathers. And among these custodial fathers, 24.7 percent of them had never been married (U.S. Census Bureau 2011). These trends are likely to continue as fathers are increasingly treated as equals in custody rulings.

Despite the importance of custody laws for shaping family structure, there has been very little research on the topic. One exception is Halla (2013), who uses state-level data to examine the effect of joint custody on a variety of family outcomes. The major findings are that the introduction of joint custody gave rise to an increase in marriage and fertility, a decline in domestic violence and suicide, and a shift from non-marital to marital births.

The other exception is Chen (2013), who finds that gender-neutral custody laws increased the likelihood of divorce and separation in the United States. Her interpretation is that gender neutrality increased men's post-divorce welfare in terms of contact with their children. As a result, they became more willing to terminate unsatisfactory marriages.

\footnotetext{
${ }^{2}$ Although many claim that courts remain biased towards mothers (see Buehler and Gerard 1995; Selfridge 2007).
} 
This paper is also about custody laws. In particular, we ask how custody laws affect the likelihood a couple will marry in the first place. Unlike prior work, we consider the effects of marriage neutrality as well as gender neutrality, and examine the interaction between the two.

Our theoretical model considers three regimes: (1) the tender years doctrine, in which custody is both marriage and gender non-neutral, (2) gender neutrality with marriage nonneutrality, and (3) gender and marriage non-neutrality. The model predicts that marriage is most likely under the tender years doctrine, and least likely when custody is marriage non-neutral and gender neutral. The marriage-neutral and gender-neutral regime is a (weakly) intermediate case.

The empirical analysis uses data on custody laws and marriage outcomes. We have compiled a unique custody law data set from a variety of sources. They include the Uniform Matrimonial and Family Laws Locator at the Legal Information Institute at Cornell University Law School and legal documents setting forth statutes and case law.

The custody data were merged with two data sets for two independent analyses. First, we use individual level data from the Fertility and Marital History Supplement of the Current Population Survey (CPS) of June 1995 to estimate Cox proportional hazard models. Second, we use state level vital statistics data to estimate state-level fixed effects models.

Both approaches give similar results. There are statistically and quantitatively significant effects of moving from the tender years doctrine to gender neutrality. There is no evidence that a subsequent move towards marriage neutrality affects the outcomes.

Section 2 of this paper tracks the evolution of custody laws throughout American history. Section 3 presents the model, and Section 4 outlines the empirical strategy. The data are described in Section 5 and the results are presented in Section 6. Section 7 concludes.

\section{Background}

\subsection{The Birth of the Tender Years Doctrine}

In colonial America, fathers had almost unlimited authority over custody of their legitimate children and neither the mother nor the father held custodial rights of a children born out of wedlock. Under the old English common law, these illegitimate children are filius nullius: 
the child and heir of no one. They bear no legally recognized relationship with either parent. The "tender years doctrine" evolved circa 1800 to replace the old English common law standard that gave preference to the father. Under this doctrine, maternal nurture was deemed the most important factor in the providing for the best interests of children of tender years (Mason 1994). This gave rise to maternal custody preference. Also by the end of the nineteenth century, an unwed mother by default was the sole custodian of her child. Since the 1960s, the tender years doctrine was gradually replaced by the "best interest of the child" standard in many states. The determination of custody rights for legitimate children in these states, at least in principle, had become gender neutral.

\subsection{The Abolition of the Tender Years Doctrine}

Family gender roles began to converge as women's labor force attachment grew in the 1970s. The tender years doctrine began to lose support as some fathers' rights groups challenged the constitutionality of the law. In Watts v. Watts (1973), the Family Court of New York declared that "application of the 'tender years presumption' would deprive respondent of his right to equal protection of the law under the Fourteenth Amendment to the United States Constitution." ${ }^{3}$ In the years that followed, several other states took the same path to declare the tender years doctrine as unconstitutional and abolished it in their family law. Custody determinations in these states were replaced by the gender-neutral "best interests of the child" standard. Note however the United States Supreme Court never decided the doctrine's constitutionality and this doctrine has not been completely abolished in the United States (see Zapata 2003). For instance, Mississippi applies the maternal preference to custody determination unless the mother is unfit.

Instead of completely abolishing maternal preference in custody determinations, some states replaced the tender years doctrine with the "primary caretaker presumption." Despite the fact that the terminology being adopted was seemingly gender neutral, this presumption in practice operates in a very gender biased manner as the overwhelming majority of primary caretakers for young children are their mothers. Consequently, this presumption has been widely

\footnotetext{
${ }^{3}$ See Watts v. Watts, 350 N.Y.S.2d 285, 290 (NY Fam. Ct. 1973).
} 
criticized especially by fathers' rights group as a maternal preference disguised as a genderneutral rule (Smith 2000).

\subsubsection{Movement Towards Recognizing the Rights of Unwed Fathers}

Along the same lines as in the gender-equality movement for custody awards, increasingly more unwed fathers became concerned about their parental rights in the 1970s. In Stanley v. Illinois (1972), the U.S. Supreme Court considered the custodial right of an unwed father to retain custody of his children upon the death of their mother. ${ }^{4}$ The Court held that:

We have concluded that all Illinois parents are constitutionally entitled to a hearing on their fitness before their children are removed from their custody. It follows that denying such a hearing to Stanley and those like him while granting it to other Illinois parents is inescapably contrary to the Equal Protection Clause.

This case marks the beginning of the "long but sporadically fought campaign to treat illegitimate children as natural children before the law greatly advanced in the last part of the twentieth century through a combination of Supreme Court decisions and statutory law" (Mason $1994,145) .^{5}$

\subsubsection{The Uniform Parentage Act 1973}

Following a series of Supreme Court decisions recognizing the rights of unmarried fathers, the National Conference of Commissioners on Uniform State Law introduced the Uniform Parentage Act in 1973. The Act extends the parent and child relationship equally to every child and every parent, regardless of the parent's marital status. It contains provisions for setting the level of child support and deals with natural father's right to obtain visitation, custody, and to withhold his consent to adoption. In the 19 states that have adopted the Uniform Parentage Act, in part or in full, custody determinations are marriage neutral once paternity has been established.

\footnotetext{
${ }^{4}$ See Stanley v. Illinois, 405 US 645 (1972).

${ }^{5}$ See also Gomez v. Perez, 409 U.S. 535, 538 (1973); Quilloin v. Walcott, 434 U.S. 246, 256 (1978).
} 
Custody is marriage neutral in some states that have not adopted the Uniform Parentage Act. These states have declared in their statutes or established through case law that nonmarital children's rights are equal to those born within marriages and the father of an illegitimate child is deemed on an equal footing with the mother as to parental and custodial rights to the child once paternity has been established. ${ }^{6}$

\section{Theory}

\subsection{Literature}

Theoretical work on non-marital unions and unwed parenthood has been quite scant. Traditional household models do not distinguish marital and non-marital unions. In Becker (1973, 815) for instance, " 'marriage' simply means that they share the same household." Subsequent household bargaining models primarily focused on analyzing the behavior of legally married unions (Manser \& Brown 1980; McElroy \& Horney 1981; Weiss \& Willis 1985). As the behavior of individuals in marital and de facto unions are driven by very different legal constraints, such theoretical treatment would limit our understanding of the behavior of the nonmarital unions gaining prominence over the past decades.

More recent theoretical developments that explicitly incorporate non-marital unions and children born outside of marriage include Willis (1999). He develops a theoretical framework that attempts to integrate theories of fertility and marriage to understand the interaction between the two decisions. The model characterizes the conditions under which non-marital equilibrium could occur. The results suggest that imbalances between number of marriageable women and men (more marriageable women than men) might be one underlying force for unwed parenthood.

Akerlof et al. (1996) develop a game theoretic framework to understand how the legalization of abortion and the advent of female contraception would result in a decline in

\footnotetext{
${ }^{6}$ For instance, Texas Family Code Section 153.003 specifically states that "The court shall consider the qualifications of the parties without regard to their marital status or to the sex of the party or the child in determining (1) which party to appoint as sole managing conservator; (2) whether to appoint a party as joint managing conservator; and (3) the terms and conditions of conservatorship and possession of and access to the child. Also for example, Kentucky has not adopted the Uniform Parentage Act, but custody allocation is nonetheless marriage neutral based on Basham v. Wilkins, 851 S.W.2d 491 (Ky. Ct. App. 1993). The court held that "the "best interests of the child" standard applies in determining custody of children born out of wedlock and gone is our preference for the mother of the illegitimate child".
} 
shotgun marriage and an increase in non-marital births. In their model, men place no value on custodial rights for their children - they merely derive utility from sexual pleasure.

Most closely related to our work is Edlund (2013). The paper presents a matching model to explain for the rising non-marital birth rate and the decline in marriage. Her model is based on the assumption that formal marriage transfers a fixed fraction of custodial rights from the wife to the husband that would otherwise be vested with the woman. Paternal rights in her model are largely confined to those in marital unions. In contrast to her model that emphasizes the role of marriage in designating paternity presumption and allocating custodial rights, our model provides additional insights into decisions when paternal custody rights are not exclusive to fathers in marital unions.

\subsection{The Model}

Figure 1 illustrates our two-period model of the effect of custody regime on marriage. At the outset a couple forms a union that produces a child. A union could be anything ranging from a casual encounter to formal marriage, and the child may be born before or after marriage. Custody probabilities in the event the union dissolves depend on marital status and custody regime. The decision to marry in period 1 is based on the probability of being granted custody in period 2.

Formally, the probability the mother is granted custody when the union dissolves is $\mathrm{p}^{\mathrm{R}} \mathrm{S}$ where $R \in\{1,2,3\}$ indicates the custody regime and $S \in\{M, N\}$ indicates the couple's marital status. $\mathrm{S}=\mathrm{M}$ when the parents marry and $\mathrm{S}=\mathrm{N}$ when they do not. The probability the father is granted custody by marital status/regime is $\left(1-\mathrm{p}^{\mathrm{R}} \mathrm{s}\right)$.

Table 1 summarizes the custody probabilities by regime and marital status. The three custody regimes are:

Regime 1: Parental gender non-neutral, marriage non-neutral. Custody is granted to the mother regardless of the parents' marital status.

Regime 2: Parental gender neutral, marriage non-neutral. If the parents are married the mother is granted custody with probability $\mathrm{p}^{2} \in(0,1)$ and the father is granted custody 
with probability $1-\mathrm{p}_{\mathrm{M}}^{2} \in(0,1)$. Custody is granted to the mother if the couple is not married. ${ }^{7}$

Regime 3: Parental gender neutral, marriage neutral. If the couple is married the mother receives custody with probability $\mathrm{p}^{3}{ }_{\mathrm{M}} \in(0,1)$. If she is not married she receives custody with probability $\mathrm{p}_{\mathrm{N}}^{3} \in(0,1)$. Because in practice, marriage may provide some advantage to fathers even under marriage neutrality, $\mathrm{p}^{3}{ }_{\mathrm{N}} \geq \mathrm{p}^{3}{ }_{\mathrm{M}}^{8}$. If there is no such advantage, $\mathrm{p}^{3}{ }_{\mathrm{N}}=$ $\mathrm{p}^{3} \mathrm{M}$

Each parent is willing to marry under Regime $\mathrm{R}$ when his or her expected utility from marriage under that regime outweighs his or her expected utility of remaining single. The mother's expected utility under Regime R when married is:

$$
\mathrm{EU}^{\mathrm{R}}{ }_{\text {Mom, } \mathrm{M}}=\alpha_{M o m}+\mathrm{p}^{\mathrm{R}}{ }_{\mathrm{M}} \varphi_{M o m}(\gamma+\delta)+\left(1-\mathrm{p}^{\mathrm{R}}{ }_{\mathrm{M}}\right) \varphi_{M o m}(\gamma)
$$

where $\alpha_{M o m}$ is her utility from marriage per se. Her utility from contact with the child is $\varphi_{\text {Mom }}(\cdot)$. If she is granted custody she has $\gamma+\delta$ time with the child, otherwise she has $\gamma \cdot{ }^{9}$ $\varphi_{\text {Mom }}(\cdot)$ is increasing and concave. ${ }^{10}$ If she does not marry her expected utility is:

$$
\mathrm{EU}^{\mathrm{R}}{ }_{\mathrm{Mom}, \mathrm{N}}=\mathrm{p}^{\mathrm{R}}{ }_{\mathrm{N}} \varphi_{M o m}(\gamma+\delta)+\left(1-\mathrm{p}^{\mathrm{R}}{ }_{\mathrm{N}}\right) \varphi_{M o m}(\gamma)
$$

\footnotetext{
${ }^{7}$ Even with the "gender-neutral custody law", the neutrality law is not completely neutral in reality. The courts tend to be biased in favor of mothers (see for instance, Buehler \& Gerard 1995; Selfridge 2005). The significance of these neutrality laws is that without these laws that grant more custody rights to the fathers, the custody would almost with certainty be vested with the mothers. We therefore would expect that $p^{2}{ }_{M}>1 / 2$. Similarly, $p^{3}{ }_{M}$ and $p^{3}{ }_{N} \geq 1 / 2$. However our results do not depend on these restrictions.

${ }^{8}$ Mason \& Quirk (1997) suggests that the marriage-neutral custody law marks unwed fathers "appreciable strides toward achieving equal footing" with that of unmarried mothers in securing custody of their children." Although a substantial number of unwed fathers had been awarded with custody, they are still typically disfavored by the court. Brown \& Cook (2011) documented the sharp differences in children's placement arrangements for married and unmarried couples in Wisconsin for those cases coming to court from 1996 through 2007. Although positive selection of fathers into marriage can be at play, their data shows that fathers were much more likely to be awarded with sole custody if they were previously married to the mothers of their child. For divorce cases, 1.3 percent and 7.6 percent of the child placement outcomes are father primary and father sole respectively, compared to 0.5 percent and 1.7 percent for the voluntary paternity acknowledgement cases.

${ }^{9}$ For instance, suppose that if she has custody she sees the child 6 days per week and if she doesn't have custody she sees the child 1 day per week. Then $\gamma=1$ and $\delta=5$.

${ }^{10}$ In a more general version of the model, utility would depend on the divorce probability, her utility in the first period from full contact with the child, and her utility in the second period if she is granted custody. We suppress these parameters as they do not affect the results as long as they do not vary with marital status.
} 
The expressions for father's utility are similar:

$$
\begin{aligned}
& \mathrm{EU}^{\mathrm{R}}{ }_{\text {Dad,M }}=\alpha_{\text {Dad }}+\left(1-\mathrm{p}^{\mathrm{R}}{ }_{\mathrm{M}}\right) \varphi_{\text {Dad }}(\gamma+\delta)+\mathrm{p}^{\mathrm{R}}{ }_{\mathrm{M}} \varphi_{\text {Dad }}(\gamma) \\
& \mathrm{EU}^{\mathrm{R}}{ }_{\text {Dad,N }}=\left(1-\mathrm{p}^{\mathrm{R}}{ }_{\mathrm{N}}\right) \varphi_{\text {Dad }}(\gamma+\delta)+\mathrm{p}^{\mathrm{R}}{ }_{\mathrm{N}} \varphi_{\text {Dad }}(\gamma)
\end{aligned}
$$

Each parent's marital surplus is the difference between his or her expected utility from marriage relative to non-marriage. That is,

$$
\mathrm{EU}^{\mathrm{R}}{ }_{\text {Mom, }, \mathrm{M}}-\mathrm{EU}^{\mathrm{R}}{ }_{\text {Mom }, \mathrm{N}}=\alpha_{M o m}+\left(\mathrm{p}^{\mathrm{R}}{ }_{\mathrm{M}}-\mathrm{p}^{\mathrm{R}}{ }_{\mathrm{N}}\right)\left[\varphi_{M o m}(\gamma+\delta)-\varphi_{M o m}(\gamma)\right]>0
$$

and

$$
\mathrm{EU}^{\mathrm{R}}{ }_{\text {Dad,M }}-\mathrm{EU}^{\mathrm{R}}{ }_{\text {Dad,N }}=\alpha_{\text {Dad }}+\left(\mathrm{p}^{\mathrm{R}}{ }_{\mathrm{N}}-\mathrm{p}^{\mathrm{R}}{ }_{\mathrm{M}}\right)\left[\varphi_{\text {Dad }}(\gamma+\delta)-\varphi_{\text {Dad }}(\gamma)\right]>0
$$

Assuming transferable utility, total marital surplus in regime $R, S^{R}$, is the sum of (5) and (6). $S^{R}$ depends on custody probabilities by marital status, utility of marriage per se and incremental utility from $\delta$ contact:

$$
\begin{aligned}
& S^{\mathrm{R}}\left(\mathrm{p}^{\mathrm{R}}{ }_{\mathrm{M}}, \mathrm{p}^{\mathrm{R}}{ }_{\mathrm{N}}\right)=\alpha_{M o m}+\alpha_{\text {Dad }}+ \\
& \quad\left(\mathrm{p}^{\mathrm{R}}{ }_{\mathrm{M}}-\mathrm{p}^{\mathrm{R}}{ }_{\mathrm{N}}\right)\left[\left(\varphi_{\text {Mom }}(\gamma+\delta)-\varphi_{\text {Mom }}(\gamma)\right)-\left(\varphi_{\text {Dad }}(\gamma+\delta)-\varphi_{\text {Dad }}(\gamma)\right)\right]
\end{aligned}
$$

The couple will be more likely to marry under regime $r$ relative to regime $q$ when the surplus under regime $r$ is greater:

$$
\operatorname{Pr}\left(\operatorname{Mar}^{r}\right)-\operatorname{PR}\left(\operatorname{Mar}^{\mathrm{q}}\right)=\operatorname{Pr}\left(S^{r}\left(p_{M}^{r}, p_{N}^{r}\right)-\left(S^{q}\left(p^{q}, p_{N}^{q}\right)\right)>0\right.
$$

where: 


$$
\begin{aligned}
& S^{r}\left(p_{M}^{r}, p_{N}^{r}\right)-\left(S^{q}\left(p^{q}{ }_{M}, p^{q}{ }_{N}\right)=\right. \\
& \left.\quad\left[\left(p^{r}{ }_{M}-p^{q}{ }_{M}\right)-\left(p^{r}{ }_{N}-p^{q}\right)\right]\left[\left(U_{M o m}(\gamma+\delta)-U_{M o m}(\gamma)\right)-\left(U_{D a d}(\gamma+\delta)\right)-U_{D a d}(\gamma)\right)\right]>0
\end{aligned}
$$

The second term within square brackets in (9):

$$
\left.\left(\mathrm{U}_{\mathrm{Mom}}(\gamma+\delta)-\mathrm{U}_{\mathrm{Mom}}(\gamma)\right)-\left(\mathrm{U}_{\mathrm{Dad}}(\gamma+\delta)\right)-\mathrm{U}_{\mathrm{Dad}}(\gamma)\right)
$$

is the difference in the mother's and father's incremental utility from having the additional $\delta$ time with the child. Consistent with theoretical work (e.g., Weiss and Willis, 1985) and a large body of empirical and biological studies, we assume that mothers have stronger preferences than do fathers for children; i.e., that (10) is positive. ${ }^{11}$

The sign of the first term:

$$
\left(\mathrm{p}_{\mathrm{M}}^{\mathrm{r}}-\mathrm{p}^{\mathrm{q}} \mathrm{M}\right)-\left(\mathrm{p}_{\mathrm{N}}^{\mathrm{r}}-\mathrm{p}_{\mathrm{N}}^{\mathrm{q}}\right)
$$

determines the direction of the effect of custody regime on the likelihood of marriage. Applying the probabilities specified earlier and summarized in Table 1 to (11) generates the predictions:

\section{H1: $\quad \operatorname{Pr}($ Marriage|Regime 1) > Pr(Marriage|Regime 2) \\ H2: $\quad \operatorname{Pr}($ Marriage|Regime 3) $>\operatorname{Pr}($ Marriage|Regime 2) \\ H3: $\quad \operatorname{Pr}($ Marriage|Regime 1) $\geq \operatorname{Pr}($ Marriage|Regime 3)}

Intuitively, H1 means that moving from tender years to gender neutrality disadvantages married relative to single mothers and, as mothers' preferences weigh more heavily than do fathers', marriage is less likely under gender neutrality. H2 means that introducing marriage neutrality mitigates the effect of the initial change. H3 compares the outcome under complete

\footnotetext{
${ }^{11}$ For instance, Kokko and Jennions (2012) offered a detailed biological explanation to which females bias towards greater care-giving. Empirical evidence that is consistent with this assertion includes Lundberg, Pollak and Wales (1993), which found that a policy that transfer child allowance from the husband to the wife within marriage increases the expenditure on children's clothing. However, fathers might derive more utilities from older sons as opposed to baby girls. (See for example Dahl \& Moretti 2008). The qualitative prediction will not be affected by the differential in utilities from additional contact with children between the mother and the father as long as the expression (10) remains positive.
} 
neutrality relative to tender years. When it is satisfied with equality the move towards marriage neutrality completely eliminates the initial negative effect of gender neutrality and the likelihood of marriage under Regime 3 is the same as under Regime 1.

\section{Estimation Strategy}

\subsection{The Hazard Model}

Our empirical analysis begins with an individual-level hazard model of the form:

$$
h\left(t, \text { GenNeutReg }_{i, \boldsymbol{s}, t}, \text { GenMarrNeutReg }_{i, s, t}, \boldsymbol{L}_{i, s, t}, \boldsymbol{X}_{i, s, t}^{I} ; \beta_{2}, \beta_{3}, \boldsymbol{\sigma}, \boldsymbol{\rho}\right)
$$

where $i$ denotes a woman; $s$ denotes state and $t$ takes value in $\{13, \ldots, 40\}$ corresponding to the woman's age.

GenNeutReg $g_{i, s, t}$ is a dummy variable indicating that respondent $i$ lived in a state under Regime 2 at age $t$. GenMarrNeutReg $g_{i, s, t}$ refers similarly to Regime 3. $\boldsymbol{L}_{i, s, t}$ is a vector of legal regime dummies including states having introduced unilateral divorce, equitable property distribution, and joint custody, along with a control for the marriage-neutral and gender nonneutral regime. $\boldsymbol{X}_{i, s, t}^{I}$ is a vector of individual-level, time-variant and time-invariant covariates including cohort dummies, race and whether the individual was at least a high school graduate. Some specifications include linear time trends or state-specific time trends.

We estimate the hazard model as a Cox proportional hazard model: $h_{0}(t) \exp \left(\beta_{2}\right.$ GenNeutReg $\operatorname{iss}_{\boldsymbol{i}, \boldsymbol{t}}+\beta_{3}$ GenMarrNeutReg $\left.g_{i, s, t}+\boldsymbol{\sigma}^{\prime} \boldsymbol{L}_{\boldsymbol{i}, \boldsymbol{s}, \boldsymbol{t}}+\boldsymbol{\rho}^{\prime} \boldsymbol{X}_{i, s, t}^{I}\right)$

where the baseline hazard, $h_{0}(t)$, conditions out and the expression:

$$
\exp \left(\beta_{2} \text { GenNeutReg }_{\boldsymbol{i}, \boldsymbol{s}, \boldsymbol{t}}+\beta_{3} \text { GenMarrNeutReg } g_{i, s, t}+\boldsymbol{\sigma}^{\prime} \boldsymbol{L}_{i, s, t}+\boldsymbol{\rho}^{\prime} \boldsymbol{X}_{i, s, t}^{I}\right)
$$


shifts the baseline multiplicatively. Hazard model results are typically interpreted as ratios where the ratio $e^{\beta_{k}}$ indicates a change of about $\left(e^{\beta_{k}}-1\right)^{*} 100$ percent in response to a one unit change in the variable $X_{k}$.

\subsection{The State-Level Fixed Effect Model}

The individual-level analysis is complemented by a state-level fixed effect model of the form:

$$
Y_{s t}=\beta_{2} \text { GenNeutReg }_{s, t}+\beta_{3} \text { GenMarrNeutReg } g_{s, t}+\boldsymbol{\mu}^{\prime} \boldsymbol{L}_{s, t}+\boldsymbol{\sigma}^{\prime} \boldsymbol{X}_{s, t}^{s}+\alpha_{t}+\gamma_{s}+\epsilon_{s, t}
$$

where $Y_{s t}$ is the marriage rate in state $\boldsymbol{s}$ in year $\boldsymbol{t}, \boldsymbol{L}_{s, t}$ is the same vector of legal regime dummies that enter the hazard model, and $\boldsymbol{X}_{s, t}^{S}$ is a vector of state-level control. $\alpha_{t}$ and $\gamma_{s}$ represent year and state dummies and $\epsilon_{s t}$ is an iid error term.

The time-series and cross-section variation, along with the set of controls, allows us to obtain estimates of the effects of custody laws on marriage rates free from bias due to state-level heterogeneity and common time effects.

\section{The Data}

The study uses data on custody and other family law variables by state and year, individual- and state-level marriage outcomes, and controls at the individual and state levels.

\subsection{Custody Laws}

Data on the timing of the changes in custody laws by state were derived from a variety of sources. The information is available on the Uniform Marital and Family Laws Locator, housed at the Legal Information Institute at the Cornell University Law School. ${ }^{12}$ Custody law in states that maintain primary caretaker presumption is considered gender non-neutral.

\footnotetext{
${ }^{12}$ The data are available at: http://www.law.cornell.edu/uniform/vol9\#paren .
} 
For some states, the year of the introduction of marriage-neutral laws was based on the passage of the Uniform Parentage Act which extends the parent and child relationship equally to every child and every parent, regardless of the marital status of the parent including the unmarried fathers' rights to custody and visitation. Marriage-neutral custody laws do not just pertain to the enactment of the Uniform Parentage Act: some states might not have the Uniform Parentage Act in their statutes but there are provisions in their codes or statutes that govern the custody rights of unmarried fathers. Also some states have the marriage-neutral custody rights of unmarried fathers established through case law under the common law system. We therefore also traced out established case law and statutes related to these custody laws from internet search engines for legal cases and state codes such as www.findlaw.com and the case law finder provided by LexisNexis. Custody laws by year and state are reported in Table 3 in Appendix II.

Figure 2 shows that the very majority of states in 1970 were under the traditional, tender years law where custody is both gender and marriage non-neutral. By 1995, the distribution of states under the gender-neutral, marriage-neutral regimes and those with both neutrality custody laws was quite even. Thirteen states (25.5 percent) had switched from the traditional custody regime to the gender-neutral but marriage non-neutral regime; 16 states (31.4 percent) had switched to the marriage-neutral custody law regimes and 17 states (33.3 percent) had both neutrality custody laws in place. In 1995 only 5 states ( 9.8 percent) remained in the traditional custody regimes, namely Idaho, Massachusetts, New York, South Carolina and Tennessee. This cross-state variation in the timing of the changes in custody regimes is the source of identification of the causal effect of the changes in custody laws on marriage.

\subsection{Other Legal Regime Variables}

Family law changed along a variety of dimensions during our period of study. We control for these changes with dummy variables indicating enactment of unilateral divorce, equitable property distribution, and joint custody laws. Data are from Friedberg (1998) Voena (2012), and Halla, (2013), respectively. ${ }^{13}$

\footnotetext{
${ }^{13}$ Except for joint custody in Washington State. Our search suggests that joint custody (known as "parenting plan" in Washington State) was enacted in 1987 (see Harrington (2009), which is available at: http://seattletimes.com/html/opinion/2008786615_opinb26harrington.html). However our results are unaffected by the change.
} 


\subsection{Individual Level Data}

Individual-level data for the hazard models are from the Fertility and Marital History Supplement of Current Population Survey (CPS) of June 1995. The supplement contains retrospective information on the marital histories of the female respondents from age 15-65. This allows us to identify their age and year of first marriage. The marital histories are only available from this one-time CPS supplement.

We need to map subjects to states to assign the laws in effect for each individual at each age. One limitation is that only the current state of residence is reported in the CPS Supplement data. Therefore we use the state of residence of individuals in 1995. This means that the assignment of legal regimes for women that moved prior to 1995 will be measured with error. If their moves were uncorrelated with the introduction of the laws, the measurement error will tend to bias the coefficients towards zero.

Controls in the individual-level analysis include respondent's birth cohort, and education, race and state of residence in 1995 when respondents ranged in age from 20 to $45 .^{14}$

Our estimates are based on the marital histories of 27,359 women born in 1950-1975 from when they were 13 until they reach age $40 .{ }^{15}$

\subsection{State Level Data}

The outcome in the state-level analysis is the total number of new marriages divided by population for each state and year for the years 1972-2009. The marriage data were collected from the Vital Statistics of the United States. The advantage of the data collected from the Vital Statistics of the United States is that it is based on marriage certificates issued in states and thus provide very accurate measures for the actual number of marriages occurring each year in different states. Data on population by state and year used to construct the denominator of the dependent variable are from the Reading Survey of Epidemiology and End Results (SEER) U.S. County Population Data. It provides information on the population in the United States at the

\footnotetext{
${ }^{14}$ Birth cohort was captured using dummy variables corresponding to 5-year intervals. Using year of birth dummies does not affect our results.

${ }^{15}$ For women born after 1955, their age ranged from 23-39 in 1995. We treat these individuals who had not married by 1995 as fixed-right censored. As this censoring mechanism is unrelated to survival time, it is uninformative and should not bias the estimates.
} 
level of the state or county by age groups and race from 1969-2009. The data on population by age groups are used to construct the marriage rate, which is defined as the number of marriages per 1000 people aged 15-54.

Controls include the proportion of the state population that is black and the logarithm of state level disposable personal real income per capita. Race data are obtained from SEER. The state level data on disposable personal income per capita was obtained from the Bureau of Economic Analysis. The CPI used to deflate income are provided by the Bureau of Labor Statistics.

We merge the state-level data with the custody and other legal regime variables to create a state-level panel data set covering 49 states plus the District of Columbia over a 38-year period. $^{16}$

\section{The Results}

\subsection{The Individual-Level Hazard Model}

The results of the hazard model are presented in Table 2. There are three specifications. Each includes the vector of legal regime variables, $\boldsymbol{L}$, the vector of individual-level covariates, $\boldsymbol{X}^{\boldsymbol{I}}$, cohort controls and state fixed effects. Specification (2) introduces a linear time trend and in specification (3) the time trends are state-specific.

Our first prediction, $\mathrm{H} 1$, is that the shift towards gender-neutral custody from tender years reduces marriage; i.e., that $\exp \left(\beta_{2}\right)<1$, or $\beta_{2}<0$. This is what we find. Estimates of $\exp \left(\beta_{2}\right)$ are between .848 and .921 , depending on specification. The ratios are highly significant in all three specifications. When custody laws are marriage neutral, gender neutrality is associated with a decline in the likelihood of marriage of approximately 7.9 to 15.2 percent.

$\mathrm{H} 2$ of our model is that, given gender neutrality, the switch from marriage non-neutrality to marriage neutrality will increase marriage. That is, we expect $\exp \left(\beta_{3}\right) / \exp \left(\beta_{2}\right)>1$, or $\beta_{3}>$

\footnotetext{
${ }^{16}$ Similar to Halla (2009), who reports that the average marriage rate in Nevada is about 12 times higher than the average of all other states, we have excluded Nevada from the state fixed effect regression analysis.
} 
$\beta_{2}{ }^{17}$ The data do not support this hypothesis. The two ratios are very similar and the ratio is insignificant. Our results are, however, consistent with H3.

\subsection{The State-Level Fixed Effects Model}

The results of the state-level analysis are reported in Table 3. The specifications are similar to the hazard model specifications. Because this is a linear model the coefficients here are interpreted as the effect of a policy change on the marriage rate.

Consistent with $\mathrm{H} 1$, the marriage rate under Regime 2 is lower than under Regime 1. In particular, the baseline model suggests that the introduction of the gender-neutral custody law reduced the state marriage rate by 1.034 per 1000 people aged 15-54 relative to the tender years regime. This is 6.8 percent of the sample mean. The estimates attenuate when we introduce state-level trends but the coefficient remains negative and highly significant. Across all specifications, we find that under gender neutrality, introducing marriage neutrality lowers the marriage rate.

There is no support for our second hypothesis that the difference between the Regime 3 and the Regime 2 coefficients is negative. In fact, the difference is positive in the first three specifications but adding a linear time trend matters. This importance of including a statespecific trend echoes Friedberg's (1998) study of the effect of unilateral divorce laws on divorce rates: Introducing the state-specific trend mediates the estimated effect of the policy variable on a marital outcome.

H3 is supported. Relative to the traditional gender non-neutral custody regime, the introduction of both gender-neutral and marriage-neutral custody laws are found to lower the state marriage rates. The magnitude varies from -.0840 to -1.983 per 1000 people aged $15-54$.

\subsection{Potential Endogeneity of Laws}

Estimates will be biased if marriage patterns induce changes in the laws, or if unobservable factors are correlated with both marriage patterns and legal regimes. In both of these cases the laws are endogenous and causal inference drawn from the results will be misleading.

\footnotetext{
${ }^{17}$ Specifically, we tested the hypothesis $\beta_{3}>\beta_{2}$ which is asymptotically equal to the hypothesis $\exp \left(\beta_{3}\right) / \exp \left(\beta_{2}\right)>1$.
} 
In order to test whether the laws are endogenous we introduce dummy variables indicating leads of the introduction of new laws into corresponding to specification 3 of Table 3 , which corresponds to Equation (16). The coefficients of the dummy variables are plotted in Figures 3 and 4 . If policy is endogenous the estimated coefficients of the leading variables of the laws will be different from zero. They are not. The relationship between the custody laws and marriage outcomes are unlikely to be driven by pre-existing trends in the marriage rate.

\section{Conclusion}

Two matters must be resolved at the dissolution of a relationship: (1) The allocation of assets, and (2) the custody of children. Causal studies have shown that divorce asset division laws affect family outcomes and partners' well-being. This study shows that custody laws matter as well. The most striking result is that the switch from the tender years doctrine to gender neutrality reduced the likelihood a woman will marry by over 7.9 percent. The finding is robust to a variety of empirical models, data sets, and specifications.

This analysis has limitations that can be addressed in future work. First, we treat fertility as exogenous but changes in custody laws might affect the decision to have children in the first place. One extension would be to endogenize the fertility decision in the theoretical model and treat fertility as endogenous in the empirical analysis.

Second, in our current model the likelihood of union dissolution does not vary with custody regime. Chen (2013) found that the switch to the gender-neutral custody regime increased the probability of divorce. Another extension would be to endogenize union dissolution.

Kramer vs. Kramer, released at the peak of the divorce revolution in 1979, portrays the outcome of a custody battle under the tender years doctrine. Joanna Kramer abandoned her husband, Ted, and their son, Billy, for many months. Her explanation was: "I never knew who I was. And that's why I had to go away. And in California I guess I've found myself." Ted learned how to manage the responsibilities of single parenthood quite effectively during her absence; as a result, his career suffered. Nevertheless, the court awarded custody to Joanna when 
she returned. ${ }^{18}$ The Oscar-winning movie resonated with a public grappling with the dilemma of assigning child custody in a period of skyrocketing divorce rates. ${ }^{19}$

Had the movie taken place at another time, or in another place, Ted, as the married father of Billy would have had a chance at custody. Under yet another set of laws he would have had a chance regardless of his marital status. This paper shows that partners' marital decisions take into account the potential outcome of a custody award should their relationship conclude with a less-than-happy Hollywood ending.

${ }^{18}$ In the end, Joanna recognized that Billy was better off with his father and relinquished custody to Ted.

${ }^{19}$ There is some debate about whether this outcome was guaranteed in the state (New York) and period during which the movie took place (see for instance, Dullea 1979). Nevertheless, it illustrates a potential outcome under the tender years regime. 


\section{References}

Akerlof, G.A., Yellen, J.L. \& Katz, M.L. (1996). An Analysis of Out-of-Wedlock Childbearing in the United States. Quarterly Journal of Economics, vol.111(2), 278-317.

Allen, D.W. (1992). Marriage and Divorce: Comment. American Economic Review, vol.82(3), 679-685.

Allen, B.D., Nunley, J.M. \& Seals, A. (2011). The Effect of Joint-Child-Custody Legislation on the Child-Support Receipt of Single Mothers. Journal of Family and Economic Issues, vol.32(1), 124-139.

Becker, G.S. (1973). A Theory of Marriage: Part I. Journal of Political Economy, vol.81(4), 813846.

Bedwell, M.A. (1979). The Rights of Fathers of Non-Marital Children to Custody, Visitation and To Consent To Adoption. U.C. Davis. Law Review, vol.12(2), 412-451.

Bergstrom, C.T. (1997). A Survey of Theories of the Family. In Handbook of Population and Family Economics, edited by Rosenzweig, M.R. \& Stark, O. Handbooks in Economics 14. Amsterdam, Netherlands: Elsevier.

Bethmann, D. \& Kvasnicka, M. (2011). The Institution of Marriage. Journal of Population Economics, vol. 24(3), 1005-1032.

Bethmann, D. \& Kvasnicka, M. (2013). World War II, Missing Men and Out of Wedlock Childbearing. Economic Journal, vol.123(567), 162-194.

Brown, P., \& Cook, S. T. (2011). Children's Placement Arrangements in Divorce and Paternity Cases in Wisconsin. Paper prepared under the Child Support Research Agreement between the Wisconsin Department of Children and Families and the Institute for Research on Poverty.

Buehler, C., \& Gerard, J. M. (1995). Divorce law in the United States: A focus on child custody. Family Relations, 439-458.

Bumpass, L \& Lu, H. (2000). Trends in Cohabitation and Implications for Children's Family Contexts in the United States. Population Studies, vol.54(1), 29-41.

Bumpass L.L., Sweet J.A. \& Cherlin A. (1991). The Role of Cohabitation in Declining Rates of Marriage. Journal of Marriage and the Family, vol. 53(4), 913-927.

Carbone, J. (2000). From Parents to Parents: The Second Revolution in Family Law. New York: Columbia University Press.

Chen, Y. (2013). Do Gender-Neutral Custody Laws Increase Divorce Rates? Working Paper, Ohio State University.

Cherow-O’Leary, R. (1987). The State-by-State Guide to Women's Legal Rights. McGraw-Hill. 
Cheung, N.S. (1972). The Enforcement of Property Rights in Children, and the Marriage Contract. Economic Journal, vol.82(326), 641-651.

Cohen, L.R. (2002). "Marriage: the Long-term Contract" in Marriage and Divorce Efficient?" in A. W. Dnes and R. Rowthorn, eds., The Law and Economics of Marriage and Divorce. Cambridge, UK: Cambridge University Press.

Columbia (1979). Kramer vs. Kramer.Dir. Robert Benton. Pers, Meryl Streep and Dustin Hoffman. Film.

Cuadra, B. (2010). Family Law- Maternal and Joint Custody Presumptions for Unmarried Parents: Constitutional and Policy Considerations in Massachusetts and Beyond. Western New England Law Review, vol.32(3), 599-659.

Dahl, G. B. \& Moretti, E. (2008). The demand for sons. The Review of Economic Studies, vol. 75(4), 1085-1120.

Dullea, G. (1979, December 21). Child Custody: Jurists Weigh Film vs. Life. New York Times, page unknown. Retrieved September 20, 2014, from

http://www.nytimes.com/packages/html/movies/bestpictures/kramer-ar.html

Edlund, L. (2005). The Role of Paternity Presumption and Custodial Rights for Understanding Marriage Patterns. Working Paper. Columbia University.

Edlund, L. (2013). The Role of Paternity Presumption and Custodial Rights for Understanding Marriage Patterns. Economica, vol.80(320), 650-669.

Edlund, L., Haider, L. \& Pande, R. (2005). Unmarried Parenthood and Redistributive Politics. Journal of the European Economic Association, vol.3(1), 95-119.

Friedberg, L. (1998). Did Unilateral Divorce Raise Divorce Rates? Evidence from Panel Data. American Economic Review, vol.88(3), 608-627.

Garfinkel, I., Meyer, D.R. \& McLanahan, S.S. (1998). A Brief History of Child Support Policies in the United States. In I. Garfinkel, S.S. Mclanahan, D.R. Meyer, \& J.A. Seltzer (Eds.), Fathers Under Fire: The Revolution in Child Support Enforcement (p.14-30). New York: Russell Sage.

Gray, J. (1998). Divorce-Law Changes, Household Bargaining, and Married Women's Labor Supply. American Economic Review, vol.88(3), 628-642.

Grossbard-Shechtman, S. (1993). On the Economics of Marriage: A Theory of Marriage, Labor, and Divorce. Boulder: Westview Press.

Gruber, J. (2004). Is Making Divorce Easier Bad for Children? The Long-Run Implications of Unilateral Divorce. Journal of Labor Economics, vol.22(4), 799-833.

Halla, M. (2009). The Effect of Joint Custody on Marriage and Divorce. IZA Discussion Paper No.4314.

Halla, M. (2013). The effect of joint custody on family outcomes. Journal of the European Economic Association, vol.11(2), 278-315. 
Harrington, B. (2009, February 25). Giving Parents Equal Parenting Time by Law. Seattle Times, page unknown. Retrieved July 20, 2014, from

http://seattletimes.com/html/opinion/2008786615_opinb26harrington.html

Hollander, S. (2012, May 07). Divorces Drag on Even After Reform. Wall Street Journal, A.19. Retrieved July 24,2014, from

http://online.wsj.com/news/articles/SB10001424052702304811304577368110112622548

Jones, C.J. (1977). The Tender Years Doctrine: Survey and Analysis. Journal of Family Law, vol.16(4), 695-751.

Kokko H, Jennions MD (2012) Sex differences in parental care. In: Royle NJ, Smiseth PT, Kölliker M, editors. The evolution of parental care. Oxford University Press. 101-118.

Krause, H.D. (1974). The Uniform Parentage Act. Family Law Quarterly, vol.8(1), 1-25.

Lehrer, E.L. (1988). Determinants of Marital Stability: A Cox-Regression Model. Applied Economics, vol.20(2), 195-210.

Lyall, S. (2002, March 24). Europeans Opting Against Marriage. New York Times, p. 1-2. Retrieved April 16, 2013, from http://www.nytimes.com

Lundberg, S. \& Pollak R.A. (2013). Cohabitation and the Uneven Retreat from Marriage in the U.S., 1950-2010. Working Paper 19413, National Bureau of Economic Research.

Lundberg, S. J., Pollak, R. A., \& Wales, T. J. (1997). Do husbands and wives pool their resources? Evidence from the United Kingdom child benefit. Journal of Human Resources, vol.32(3), 463-480.

Manser, M. \& Brown, M. (1980). Marriage and Household Decision-Making: A Bargaining Analysis. International Economic Review, vol.21(1), 31-44.

Mason, M.A. (1994). From Father's Property to Children's Rights: the History of Child Custody in the United States. New York: Columbia University Press.

Mason, M.A. (2012). The Roller Coaster of Child Custody Law over the Last Half Century. Journal of the American Academy of Matrimonial Lawyers, vol.24(2), 451-466.

McElroy, M.B. \& Horney, M.J. (1981).Nash-Bargained Household Decisions: Toward a Generalization of the Theory of Demand. International Economic Review,vol.22(2), 333-349.

McElroy, M. B. (1990). The empirical content of Nash-bargained household behavior. Journal of human resources, vol.25(4), 559-583.

Meyer, D.R. \& Garasky, S. (1991). Custodial Fathers: Myths, Realities, and Child Support Policy. Technical Analysis Paper no.42.

Michael, R.T. \& Tuma, N.B. (1985). Entry into Marriage and Parenthood by Young Men and Women: the Influence of Family Background. Demography, vol.22(4), 525-544.

Mincy, R., Garfinkel, I. \& Nepomnyaschy, L. (2005). In-Hospital Paternity Establishment and Father Involvement in Fragile Families. Journal of Marriage and Family, vol.67(3), 611-626. 
Neal, D. (2004). The Relationship Between Marriage Market Prospects and Never-Married Motherhood. Journal of Human Resources, vol.49(4), 938-957.

Norton, E.C., Wang, H. \& Ai, C. (2004). Computing Interaction Effects and Standard Errors in Logit and Probit Models. Stata Journal, vol.4(2), 154-167.

Nunley, J.M. \& Seals Jr. R.A. (2011). Child-custody Reform, Marital Investment in Children, and the Labor Supply of Married Mothers. Labour Economics, vol.18(1), 14-24.

Parkman, A.M. (1992). Unilateral Divorce and the Labor Force Participation Rate of Married Women, Revisited. American Economic Review, vol.82(3), 671-678.

Peters, H.E. (1986). Marriage and Divorce: Informational Constraints and Private Contracting. American Economic Review, vol.76(3), 437-454.

Rasul, I. (2004). The impact of divorce laws on marriage. Unpublished manuscript, University of Chicago.

Rasul, I. (2006). The Economics of Child Custody. Economica, vol.73(289), 1-25.

Selfridge, A. (2007). Equal Protection and Gender Preference in Divorce Contests Over Custody. J. Contemp. Legal Issues, vol.16, 165.

Seltzer, J.A. (2000). Families Formed Outside of Marriage. Journal of Marriage and Family, vol.62(4), 1247-1268.

Smith, P.L. (2000). The Primary Caretaker Presumption: Have We Been Presuming Too Much? Indiana Law Journal, vol.75(2), 731-746.

Stevenson, B. (2007). The Impact of Divorce Laws on Marriage-Specific Capital. Journal of Labor Economics, vol. 25(1), 75-94.

Stevenson, B., \& Wolfers, J. (2006). Bargaining in the shadow of the law: Divorce laws and family distress. The Quarterly Journal of Economics, vol.121(2), 267-288.

Tach, L., Mincy, R. \& Edin, K. (2010). Parenting as a "Package Deal": Relationships, Fertility, and Nonresident Father Involvement Among Unmarried Parents. Demography, vol.47(1), 181204.

Tuma, N.B. \& Michael, R.T. (1986). A Comparison of Statistical Models for Life Course Analysis with an Application to First Marriage. In Family relations in life course perspective, edited by Kertzer, D.I. and Blau, Z.S. Greenwich, Connecticut, JAI Press.

U.S. Census Bureau (2011). Custodial Mothers and Fathers and Their Child Support: 2009, Current Population Reports. Available at: http://www.census.gov/prod/2011pubs/p60-240.pdf, (accessed on Jul. 6 2014).

U.S. Vital Statistics (2013). Births: Final Data for 2011. National Vital Statistics Reports, vol.62(1). Available at: http://www.cdc.gov/nchs/data/nvsr/nvsr62/nvsr62_01.pdf, (accessed on January 30, 2014). 
Wardle, L.D. \& Nolan, L.C. (2011). Family Law in the United States. The Netherlands: Kluwer Law International BV.

Weiss, Y. \& Willis, R.J. (1985). Children as Collective Goods and Divorce Settlements. Journal of Labor Economics, vol.3(3), 268-292.

Weitzman, L. (1985). The Divorce Revolution: The Unexpected Social and Economic Consequences for Women and Children in America. New York: Free Press. Willis, R.J. (1999). A Theory of Out-of-Wedlock Childbearing. Journal of Political Economy, vol.107(6), S33-S64.

Wolfers, J. (2006). Did Unilateral Divorce Law Raise Divorce Rates? A Reconciliation and New Results. American Economic Review, vol.96(5), 1802-1820

Zapata, R. (2003). Child Custody in Texas and the Best Interest Standard: In the Best Interest of Whom. Scholar, vol.6, 197-217. 
Figure 1: Timeline of Events

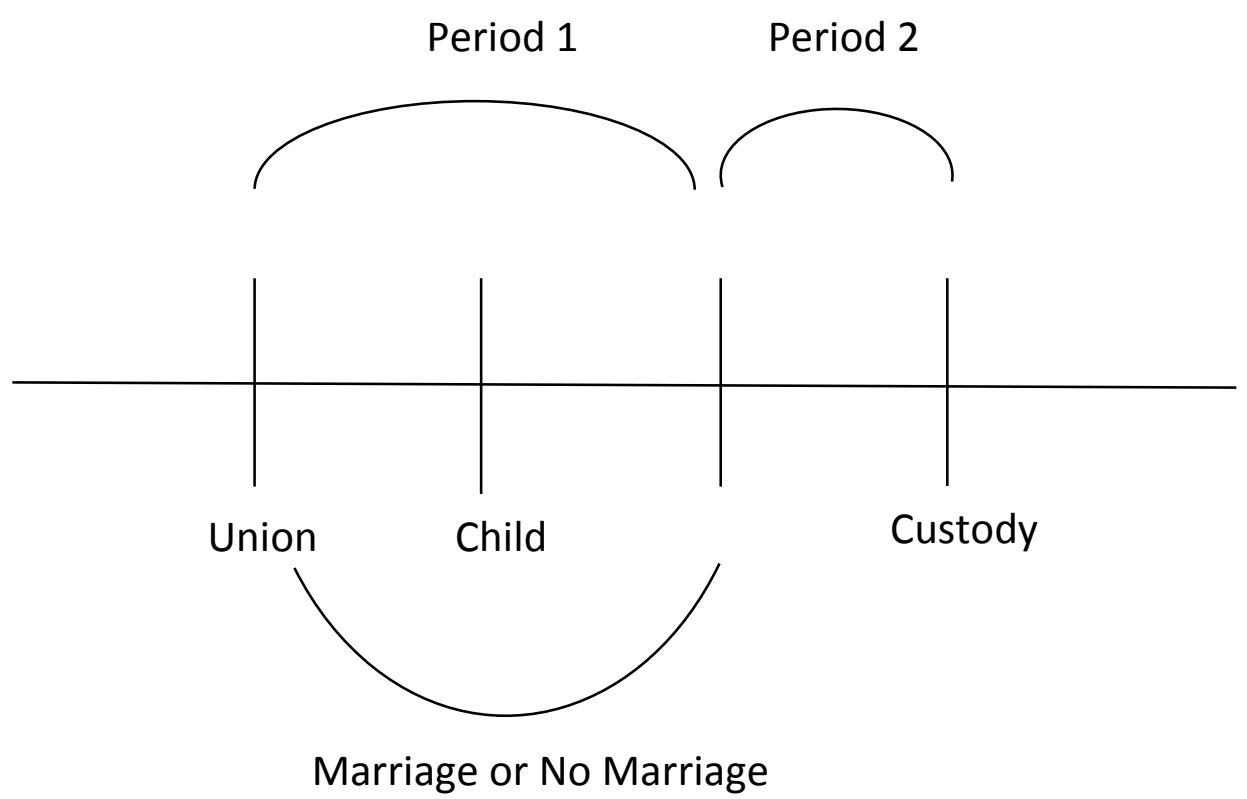


Figure 2: Custodial Regime Distribution of States as at Year 1970 and 1995

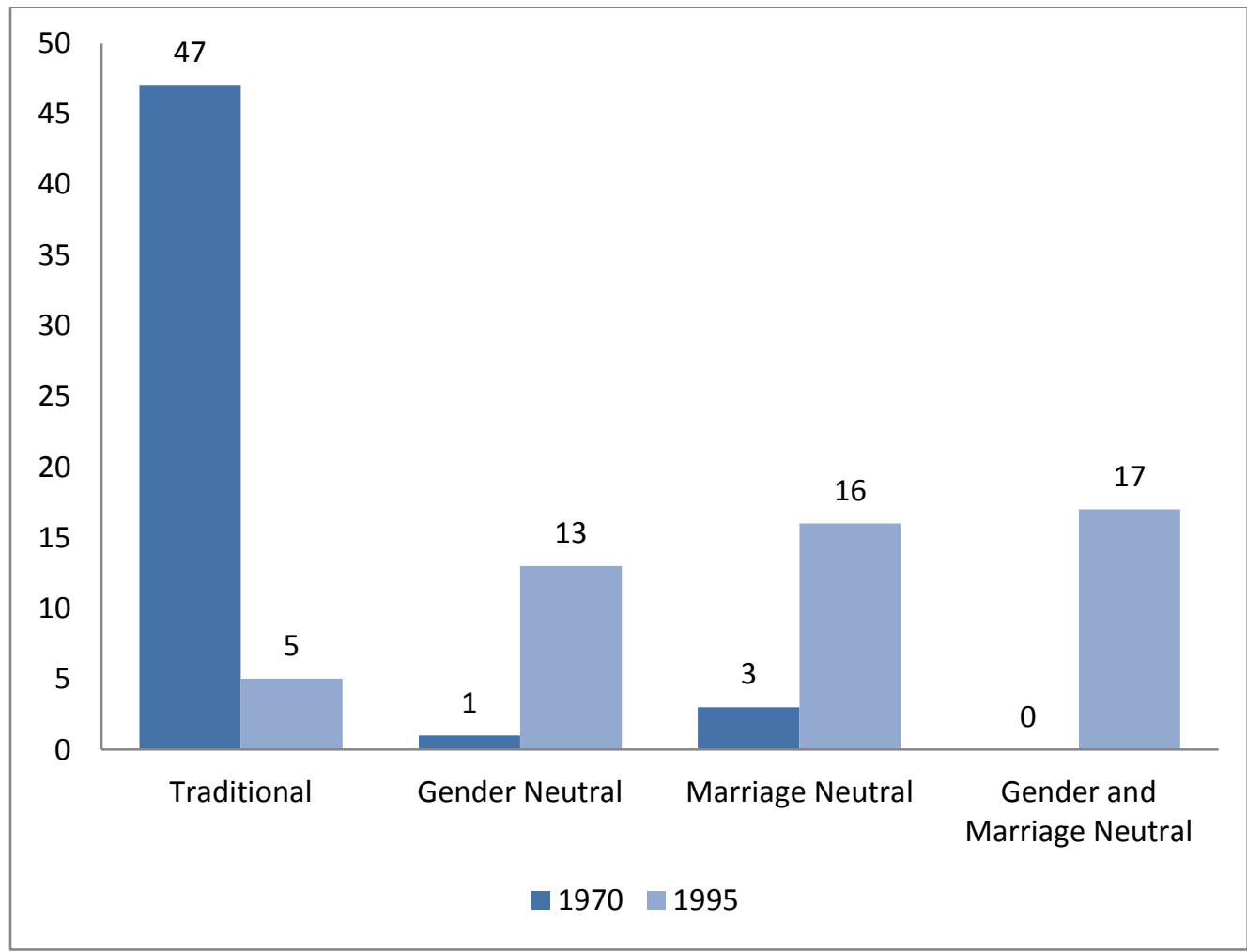


Figure 3: Check for Pre-Existing Trends in Marriages Rates for the Gender-Neutral Custody Law

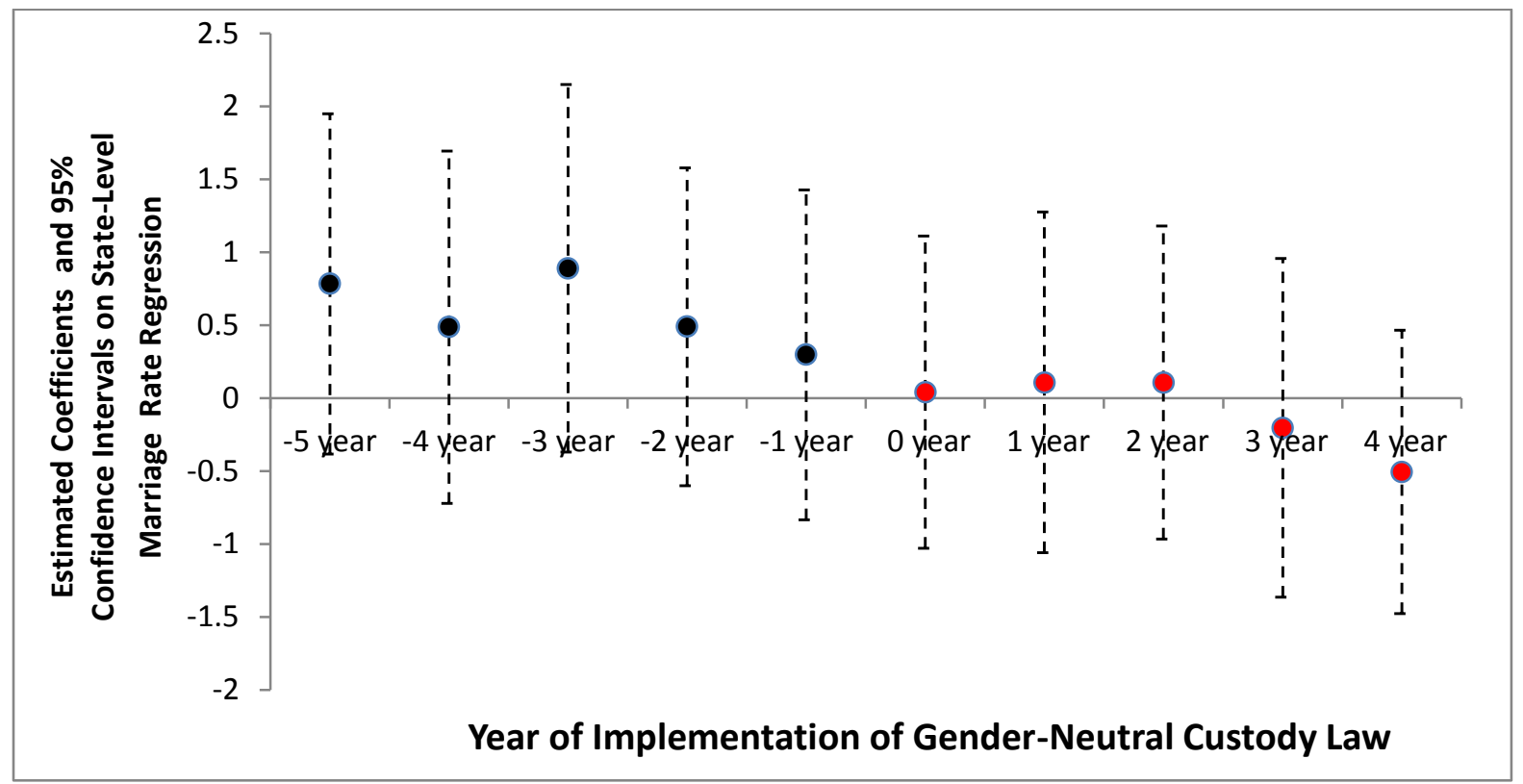

Figure 4: Check for Pre-Existing Trends in Marriages Rates for the Marriage-Neutral Custody Law

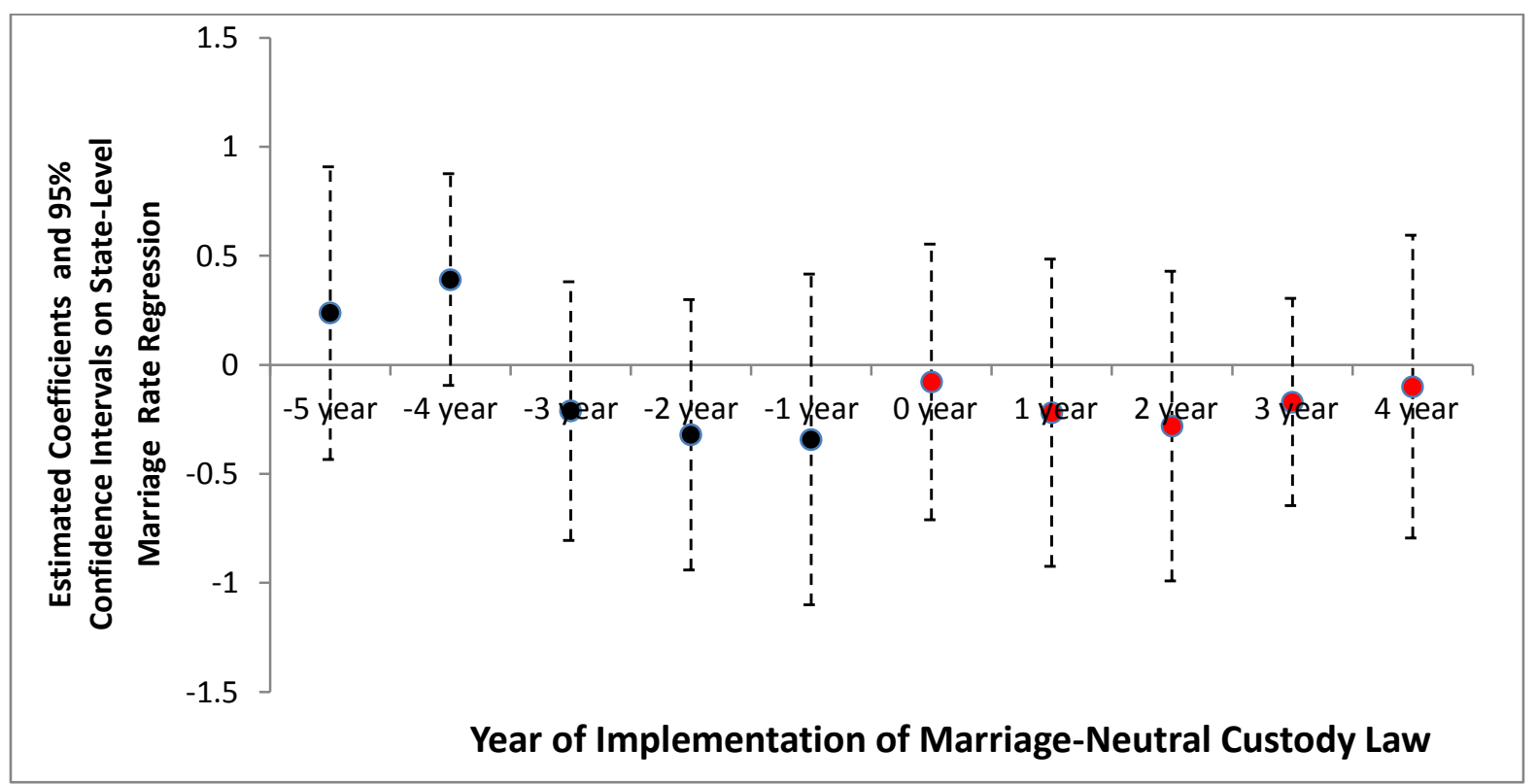


Table 1: Custody Probabilities by Regime

\begin{tabular}{l}
\hline Custody Granted to Mother \\
$\begin{array}{l}\text { Married } \\
\left(p^{R}{ }_{M}\right)\end{array}$
\end{tabular}


Table 2: Hazard Models for Marriage of Women Born in 1950-1974

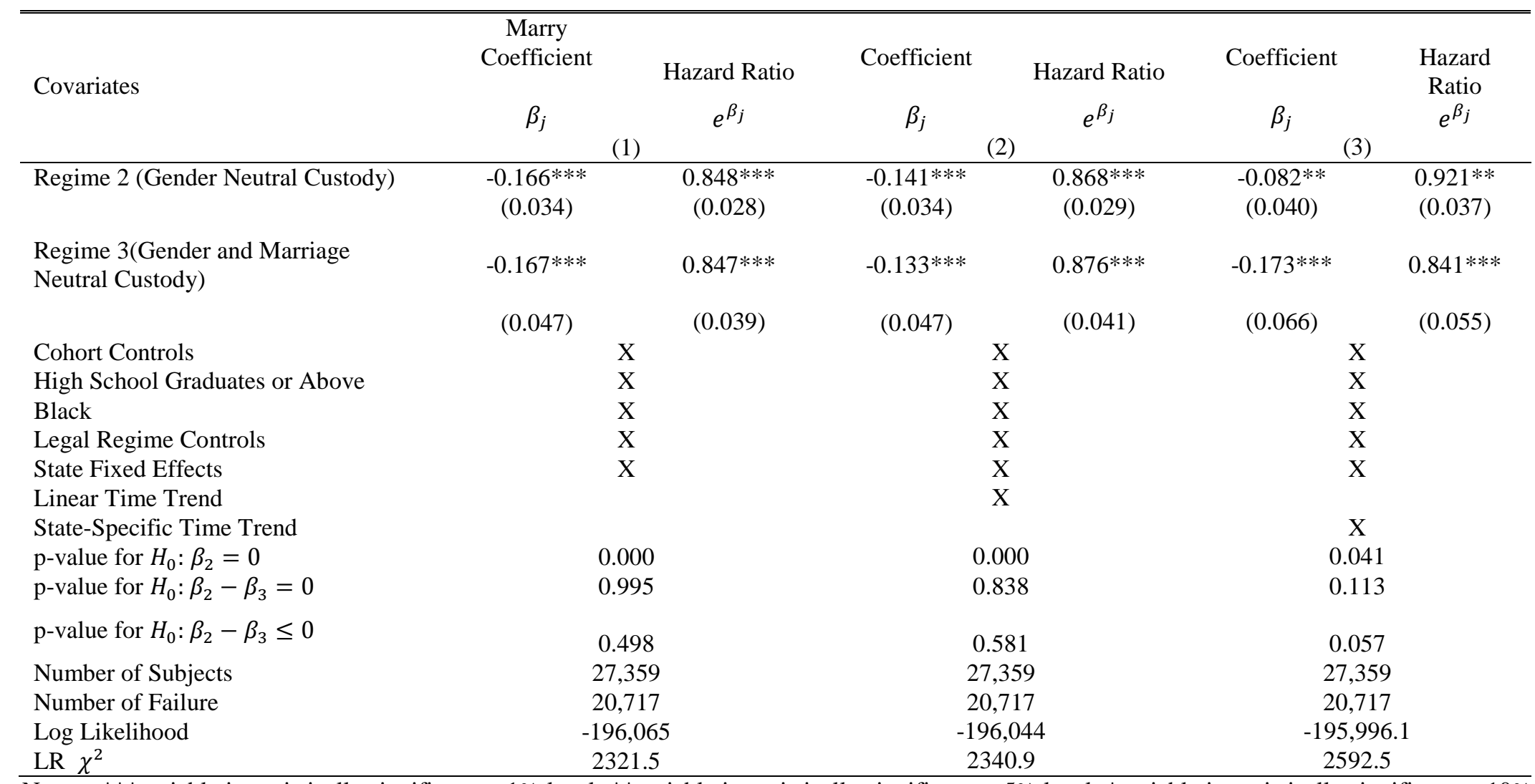

Notes: ***variable is statistically significant at $1 \%$ level; **variable is statistically significant at $5 \%$ level; *variable is statistically significant at $10 \%$ level. Robust standard are in brackets. The time-invariant covariates include dummies for respondents born in 1950-54,1955-1959,1960-1964,19651969,1970-1974, a dummy for black, state of residence for respondents and high school graduates or above. Time-variant covariates include dummy variables that indicate the state of residence of the respondent is under the unilateral divorce, equitable property distribution, community property, joint-custody and marriage neutral custody regime. Data source: Current Population Survey Marital and Fertility Supplement 1995 
Table 3: The Effect of Gender and Marriage Neutral Custody Laws on the State Level Marriage Rates

\section{Dependent Variables: Marriage Rate}

\section{Independent Variables:}

(1)

\begin{tabular}{|c|c|c|c|}
\hline $\begin{array}{l}\text { Regime } 2 \text { (Gender- } \\
\text { Neutral Custody) }\end{array}$ & $\begin{array}{c}-1.034 * * * \\
(0.301)\end{array}$ & $\begin{array}{c}-1.344 * * * \\
(0.313)\end{array}$ & $\begin{array}{c}-0.642 * * * \\
(0.221)\end{array}$ \\
\hline $\begin{array}{l}\text { Regime } 3 \text { (Gender-and } \\
\text { Marriage-Neutral } \\
\text { Custody) }\end{array}$ & $\begin{array}{c}-1.688 * * * \\
(0.355)\end{array}$ & $\begin{array}{c}-1.983 * * * \\
(0.340)\end{array}$ & $\begin{array}{c}-0.840 * * * \\
(0.257)\end{array}$ \\
\hline Legal Regime Controls & $\mathrm{X}$ & $X$ & $X$ \\
\hline State Demographics & $\mathrm{X}$ & $\mathrm{X}$ & $\mathrm{X}$ \\
\hline State Fixed Effects & $X$ & $X$ & $X$ \\
\hline Linear Time Trend & $\mathrm{X}$ & & \\
\hline Time Dummies & & $\mathrm{X}$ & \\
\hline $\begin{array}{l}\text { State-Specific Time } \\
\text { Trend }\end{array}$ & & & $X$ \\
\hline $\mathrm{p}$-value for $H_{0}: \beta_{2}=0$ & 0.001 & 0.000 & 0.004 \\
\hline $\begin{array}{l}\text { p-value for } H_{0}: \beta_{2}- \\
\beta_{3}=0\end{array}$ & 0.004 & 0.002 & 0.339 \\
\hline $\begin{array}{l}\mathrm{p} \text {-value for } H_{0}: \beta_{2}- \\
\beta_{3} \leq 0\end{array}$ & 0.002 & 0.001 & 0.170 \\
\hline $\mathrm{N}$ & 1,890 & 1,890 & 1,890 \\
\hline R-squared & 0.824 & 0.840 & 0.922 \\
\hline
\end{tabular}

Notes: ***variable is statistically significant at $1 \%$ level; **variable is statistically significant at $5 \%$ level; *variable is statistically significant at $10 \%$ level. Robust standard errors clustered at the state-year level are in brackets. Legal regime controls include dummy variables that indicate the state is under the unilateral divorce, equitable property distribution, community property, joint-custody and the marriage neutral custody regime; state demographics include the state-level proportion of black population and the logarithm form of state level disposable personal real income per capita. The regressions are weighted by the state population. Data: Vital Statistics of the United States; the Reading Survey of Epidemiology and End Results (SEER) U.S. County Population Data; Bureau of Labor Statistics; Bureau of Economic Analysis. 


\section{Appendix I: Summary Statistics}

Table 1: Descriptive Statistics: State Level Analysis (1972-2009)

\begin{tabular}{|c|c|c|c|c|c|}
\hline Variables & $\mathrm{N}$ & Min & Mean & $\operatorname{Max}$ & $\begin{array}{l}\text { Standar } \\
\text { d Error }\end{array}$ \\
\hline \multicolumn{6}{|l|}{ State Demographics } \\
\hline $\begin{array}{l}\text { State level number of marriages } \\
\text { per } 1000 \text { population aged } 15-54\end{array}$ & 1,890 & 5.14 & 15.27 & 41.09 & $(4.04)$ \\
\hline $\begin{array}{l}\text { State level proportion of population age } 15 \text { - } \\
54\end{array}$ & 1,901 & 50.00 & 56.76 & 65.02 & $(1.90)$ \\
\hline State level proportion of black population & 1,901 & 5.705 & 30.73 & 41.20 & $(5.25)$ \\
\hline $\begin{array}{l}\text { State level per capita disposable personal } \\
\text { income in } 1982 \text { dollars }\end{array}$ & 1,901 & 6928 & 12,752 & 28,784 & $(3160)$ \\
\hline \multicolumn{6}{|l|}{ Legal Regimes } \\
\hline Unilateral divorce regime & 1,901 & 0 & 0.816 & 1 & $(0.388)$ \\
\hline Equitable distribution regime & 1,901 & 0 & 0.614 & 1 & $(0.487)$ \\
\hline Community property regime & 1,901 & 0 & 0.265 & 1 & $(0.442)$ \\
\hline Joint custody regime & 1,901 & 0 & 0.753 & 1 & $(0.431)$ \\
\hline $\begin{array}{l}\text { Gender-and marriage non-neutral custody } \\
\text { regime (Regime } 1 \text { ) }\end{array}$ & 1,901 & 0 & 0.223 & 1 & $(0.417)$ \\
\hline Gender-neutral custody regime (Regime 2) & 1,901 & 0 & 0.220 & 1 & $(0.414)$ \\
\hline $\begin{array}{l}\text { Gender-and marriage-neutral custody } \\
\text { regime (Regime } 3 \text { ) }\end{array}$ & 1,901 & 0 & 0.335 & 1 & $(0.472)$ \\
\hline $\begin{array}{l}\text { Marriage-neutral custody regime (Regime } \\
\text { 4) }\end{array}$ & 1,901 & 0 & 0.221 & 1 & $(0.415)$ \\
\hline
\end{tabular}


Table 2: Descriptive Statistics: CPS Marital and Fertility Supplement 1995

\begin{tabular}{|c|c|c|c|c|c|}
\hline Covariates & $\mathrm{N}$ & Min & Mean & Max & $\begin{array}{l}\text { Standard } \\
\text { Error }\end{array}$ \\
\hline \multicolumn{6}{|l|}{ Individual Characteristics } \\
\hline $\begin{array}{l}\text { Age of first marriage conditional on } \\
\text { number of marriage }>=1\end{array}$ & 20,756 & 11 & 21.8 & 45 & $(4.422)$ \\
\hline High school or above education & 27,359 & 0 & 0.894 & 1 & $(0.307)$ \\
\hline Less than high school graduates & 27,359 & 0 & 0.106 & 1 & $(0.307)$ \\
\hline High school graduates only & 27,359 & 0 & 0.643 & 1 & $(0.479)$ \\
\hline Degree or above education & 27,359 & 0 & 0.251 & 1 & $(0.434)$ \\
\hline Black & 27,359 & 0 & 0.115 & 1 & $(0.319)$ \\
\hline \multicolumn{6}{|l|}{ Legal Regimes } \\
\hline Unilateral divorce regime by age 20 & 20,158 & 0 & 0.671 & 1 & $(0.469)$ \\
\hline Equitable distribution regime by age 20 & 20,158 & 0 & 0.577 & 1 & $(0.494)$ \\
\hline Community property regime by age 20 & 20,158 & 0 & 0.186 & 1 & $(0.389)$ \\
\hline Joint custody regime by age 20 & 20,158 & 0 & 0.477 & 1 & $(0.499)$ \\
\hline $\begin{array}{l}\text { Under gender-and marriage non-neutral } \\
\text { custody regime (regime } 1 \text { ) by age } 20\end{array}$ & 20,158 & 0 & 0.408 & 1 & $(0.492)$ \\
\hline $\begin{array}{l}\text { Under gender-neutral custody regime } \\
\text { (Regime } 2 \text { ) by age } 20\end{array}$ & 20,158 & 0 & 0.245 & 1 & $(0.476)$ \\
\hline $\begin{array}{l}\text { Under gender-and marriage neutral } \\
\text { custody regime (Regime } 3 \text { ) by age } 20\end{array}$ & 20,158 & 0 & 0.108 & 1 & $(0.311)$ \\
\hline $\begin{array}{l}\text { Under marriage-neutral custody regime } \\
\text { (Regime } 4 \text { ) by age } 20\end{array}$ & 20,158 & 0 & 0.239 & 1 & $(0.426)$ \\
\hline
\end{tabular}


Appendix II: Years of the Introduction of the Neutrality Custody Laws

Table 3: Years of the Introduction of the Neutrality Custody Laws

\begin{tabular}{|c|c|c|c|c|c|}
\hline State & $\begin{array}{l}\text { Gender } \\
\text { Neutral }\end{array}$ & $\begin{array}{l}\text { Marriage } \\
\text { Neutral }\end{array}$ & State & $\begin{array}{l}\text { Gender } \\
\text { Neutral }\end{array}$ & $\begin{array}{l}\text { Marriage } \\
\text { Neutral }\end{array}$ \\
\hline Alabama & 1981 & 1984 & $\begin{array}{l}\text { North } \\
\text { Carolina }\end{array}$ & 1977 & 2003 \\
\hline Alaska & 1977 & 1989 & North Dakota & - & 1979 \\
\hline Arizona & 1973 & - & Ohio & - & 1982 \\
\hline Arkansas & 1987 & - & Oklahoma & 1986 & 2006 \\
\hline California & - & 1975 & Oregon & - & 1975 \\
\hline Colorado & 1983 & 1962 & Pennsylvania & - & 1977 \\
\hline Connecticut & 1970 & 1985 & Rhode Island & - & 1975 \\
\hline Delaware & - & 1983 & $\begin{array}{l}\text { South } \\
\text { Carolina }\end{array}$ & 1996 & - \\
\hline $\begin{array}{l}\text { District of } \\
\text { Columbia }\end{array}$ & 1972 & 1996 & South Dakota & 1979 & - \\
\hline Florida & - & 1988 & Tennessee & 1997 & - \\
\hline Georgia & 1975 & 1973 & Texas & 1974 & 1995 \\
\hline Hawaii & 1976 & 1975 & Utah & - & 2005 \\
\hline Idaho & - & 1996 & Vermont & - & 1989 \\
\hline Illinois & 1975 & 1984 & Virginia & 1982 & - \\
\hline Indiana & 1977 & - & Washington & 1981 & 1980 \\
\hline Iowa & - & 1988 & West Virginia & - & 1973 \\
\hline Kansas & 1977 & 1985 & Wisconsin & 1981 & 1995 \\
\hline Kentucky & 1974 & 1993 & Wyoming & 1977 & 1965 \\
\hline Louisiana & 1979 & 1994 & & & \\
\hline Maine & 1981 & 1995 & & & \\
\hline Maryland & 1978 & 1952 & & & \\
\hline Massachusetts & - & - & & & \\
\hline Michigan & 1971 & 2003 & & & \\
\hline Minnesota & - & 1980 & & & \\
\hline Mississippi & - & 1983 & & & \\
\hline Missouri & - & 1982 & & & \\
\hline Montana & - & 1977 & & & \\
\hline Nebraska & 1976 & - & & & \\
\hline Nevada & 1979 & 1979 & & & \\
\hline New & 1975 & 2005 & & & \\
\hline Hampshire & 1915 & & & & \\
\hline New Jersey & - & 1983 & & & \\
\hline New Mexico & 1971 & 1978 & & & \\
\hline New York & - & 2006 & & & \\
\hline
\end{tabular}

